\title{
Portfolio Management and Profitability of Commercial Banks
}

\author{
Andrews Doeh Agblobi ${ }^{*}$, Oscar Tornam Yaw Kuhorfah, Prisca Asamoah \\ Department of Banking \& Finance, University of Professional Studies, Accra, Ghana \\ Email address: \\ a_agblobi@yahoo.com (A. D. Agblobi) \\ ${ }^{*}$ Corresponding author \\ To cite this article: \\ Andrews Doeh Agblobi, Oscar Tornam Yaw Kuhorfah, Prisca Asamoah. Portfolio Management and Profitability of Commercial Banks. \\ Journal of Business and Economic Development. Vol. 5, No. 4, 2020, pp. 244-248. doi: 10.11648/j.jbed.20200504.17
}

Received: November 11, 2020; Accepted: November 23, 2020; Published: November 30, 2020

\begin{abstract}
Banks optimally invest to earn profit as they consider the associated risks with such portfolio management. Portfolio management is a medium by which the banks hold investment due from other banks, purchase Government securities and invest in subsidiaries. This paper investigates the effect of banks' portfolio management on profitability. Five commercial banks that are listed on the Ghana Stock Exchange were randomly selected for the study. Data on the total market value of Government securities, investment in subsidiaries and due from other banks were collected from the Bank of Ghana and the Ghana Stock Exchange between 2008 and 2017. As panel study, we regress portfolio management on profitability. The findings show that holding of government securities and investing in subsidiaries have a significant positive effect on the profitability of banks in Ghana. The findings also show that non-performing loans have a significant negative effect on the profitability of the banks. Therefore, it is recommended that banks should develop a balance between holding government securities and investing in subsidiaries to improve upon its profitability. The banks should also double their efforts to reduce their non-performing loans by enhancing the skills of its officers, strengthening its due diligence procedures and intensify monitoring activities.
\end{abstract}

Keywords: Portfolio Management, Performance, Investment, Banks, Profitability

\section{Introduction}

The paper investigates the relationship between portfolio management and profitability of commercial banks. Portfolio management is increasingly an important aspect of banking such that individual banks as well as financial institutions structure their collection of assets in a manner that will add value to their investments. The assets that are held are constructed to maximize returns and minimize the expected risk. The construction of an efficient portfolio enables banks to diversify their risks and improve their earnings ability [14, 12]. Between 2017 and 2019, about 435 banks and other deposits taking institutions collapsed in Ghana. The Bank of Ghana and Securities and Exchange Commission (SEC) that regulate these financial institutions stated that the institutions' inability to meet the minimum capital requirement, poor corporate governance, liquidity problem and high default risk, as well as poor assets management, caused the revocation of their licenses. As at the end of 2019, there was a total of 23 Commercial Banks in Ghana, a dropped from 34 banks in
2017. A total of nine Commercial Banks collapsed and about four entered into merger with existing banks.

Banks solicits for deposits from small and large customers to make loans, operate payment systems and provide a mechanism for the transmission of the monetary policy [15]. The banks hold those portfolios of assets and attempt to structure them to maximize returns. They also increase the products base to attract more customers to maximize their profitability.

This study contributes as the first empirical study into the investigation of portfolio management and profitability of commercial banks. A few studies that exist rather focused on an aspect of the portfolio management such as diversification or assets allocation see $[1,5,13]$.

Portfolio management is assets allocation, diversification and rebalancing of the asset to a set upper limit. Asset allocation is the apportioning of the holdings within the portfolio across risky and risk-free asset classes. Usually, investment requires a well-thought-out design of the statement of investment policy that captures investors' 
unique needs. Diversification is sharing of risk and reward within asset classes as it is difficult to know which particular subset of assets class is likely to outperform another. Therefore, diversification is the process of expanding the number of assets within the portfolio to minimize investment risk. Investment within the banking sector has become compelling to institutional portfolio managers in developed countries because diversification provides higher portfolio returns and reduces risk [13]. The diversification of asset classes also contributes to improving performance in developing countries financial institutions [5]. Rebalancing is the repositioning of assets to its original target allocation at a given period or for retaining the asset mix that best reflects an investor's risk and returns profile. Portfolio rebalancing can be seen as an instance of the risk-taking channel of monetary policy, applied to a specific case of asset purchase programme [2]. Thus, rebalancing relates to ensuring that the portfolio is aligned to the minimum and maximum asset allocation set-out in the investment policy statement. The aim is to reduce excessive or over-concentration in a particular asset class. The poor performance of numerous financial institutions is due to over-concentration and non-performance in those assets class [8]. They noted that poor performance arising from assets allocation is repeatedly linked to a strategic error committed over time.

Very limited studies have been conducted on portfolio management through government securities, investment in subsidiaries and due from other banks and their effects on the profitability of banks. A study by [1] on portfolio management and profitability in early-nineteenth-century banking and postulated that the key to profit generations in the banks was asset management and liability management. The author noted that asset management involves choosing the appropriate balance between earning assets, non-earning assets and a mix of income-producing financial papers (i.e. money market instruments). The author divided the banks earning assets into two: loans and investments. The component of the investment portfolio was summarised as the purchase of Government securities, equity investments in other entities and taking advantage of fund balances due to other banks (i.e. idle balances). The author demonstrated how substantial some banks holding of Government securities that ran into billions of US Dollars, reported large profits. The question worth investigating is what is the effect of portfolio management on the profitability of commercial banks in Ghana?

The problem with [1] study was the definition of 'loans as the banks' acquisition of short-term (less than one year) debt instruments' while 'investment as the purchase of longerterm earning assets'. The concern is that banks also offer short-term investments through their fixed deposits such as 91-Days or 182 Day instruments to attract funds to on-lend to others. So, rather than using periods to distinguish between loans and investment, the features and nature of the financial asset should be used. For instance, banks offer loans with tenor for more than one year.

The rest of the paper is organized such that Section 2 presents method and materials used for the study, and Section 3 highlights the findings and 4 discusses the conclusion of the study.

\section{Method and Materials}

\subsection{Empirical Model Specification}

The focus of this paper is to investigate the effect of portfolio management on the profitability of commercial banks in Ghana. Portfolio management is a measure of allocation of assets mix of commercial banks to include government securities, investment in subsidiaries and due from other financial institutions. To address the objective, profitability is stated as a function of portfolio management and other characteristics in "(1)" as follows.

$$
y_{t}=f\left(\sum \pi_{t}, c_{t}, \varepsilon_{t}\right)
$$

where $y_{t}$ is the profitability of banks, sigma $\left(\sum \pi_{t}\right)$ denotes portfolio management which is measured as a collection of asset classes held by the bank to include government securities, investment in subsidiaries and due from other financial institutions. Let $c_{t}$ represent other characteristics. The model in "(1)" is specified in a functional form in "(2)" as follows:

$$
\begin{aligned}
\text { profit }_{t} & =\beta_{0}+\beta_{1} \log \left(\text { govsec }_{t}\right)+\beta_{2} \log \left(\text { invsub }_{t}\right)+\beta_{3} \log \left(\text { duefi }_{t}\right) \\
& +\beta_{4} \log \left(\text { conspr }_{t}\right)+\beta_{5} \log \left(\text { nonpl }_{t}\right)+\varepsilon_{t}
\end{aligned}
$$

where profit $t_{t}$ denotes profitability that is measured as the ratio of net income to total assets during the year $t, g o v \mathrm{sec}_{t}$ measures government securities held by banks during the year $t$, invsub ${ }_{t}$ measures the total value of the investment in subsidiaries during the period $t$, duefi $i_{t}$ measures the total value of holding due from other financial institution during the year $t$, conspr $r_{t}$ is the annual value of consumer price index, nonpl is the annual percentage of a non-performing loan of banks during the period $t$. The $\varepsilon_{t}$ is the error term at time $t$. The study used logarithm for independent variables to narrow the range. This was particularly important because of the large monetary values involved. The dependent variable was a ratio that was between zero and one that did not require logs.

\subsubsection{Dependent Variable}

The study employed return on asset (ROA) as the dependent variable. The return on assets is an indicator of how profitable an organization is relative to its whole assets [9]. ROA shows how efficient a bank's management is utilizing its total assets to generate earnings [3]. The ROA ratio was used because the portfolio of Banks are holdings of other entities assets since it measures the ability of their earnings on the return of that asset it was convenient to use it. 


\subsubsection{Independent Variable}

The independent variables used for the investigation was portfolio management which is categorized into government securities, investment in subsidiaries and due from other financial institutions.

\section{Government Securities}

Government Securities are debt obligations that are issued by the central government with a promise of repayment upon the security's maturity date. These securities are low-risk investments issued to individuals, companies and foreign investors with the promise to repay on maturity [6]. The government issues this investment security to either raise funds for government capital expenditures such as the construction of hospitals, roads, other public infrastructure facilities and to retire maturing public debts. There are different types of government securities which include treasury bills such as 91 days or 182days bills. Treasury notes whose maturity periods are longer than treasury bills and treasury bonds with a maturity period of about 20years. The government also issued different bonds such as Sovereign bonds and Euro bonds. Banks purchase government securities as a way to diversify their portfolio into low risk but high return especially in Ghana [7].

\section{Investment in Subsidiaries}

Investment in subsidiaries is a bank which holds a controlling equity interest of $50 \%$ and above in another bank or diversifying into other non-banking ventures. They are separate and distinct legal entities from their parent banks which show the independence of liabilities, tax and governance. A subsidiary bank can sue and be sued separately from its parent bank. Banks invest in subsidiaries as a form of expansion of its activities and expects additional income from such venture (i.e. mining, insurance and others).

Due from other Financial Institutions

Due from other financial institutions is asset accounts in the general ledger that indicates the number and amount of deposits and loans currently held by the bank due to another bank and other financial institutions [1]. The accounts are used to facilitate collection of cash and non-cash items, transfer and settlement of security transactions, transfer of participation-loan funds, the purchase or sale of Central Bank funds, and for many other purposes. Balances due to institutions cover all interest-bearing and noninterest-bearing balances whether in the form of demand, savings, or time balances [10].

\subsubsection{Control Variables}

The control variables were the Consumer Price Index (CPI) and Non-Performing Loans (NPL). The consumer price index is a measure of changes in the price level of a market basket of consumer goods and services purchased by the household such as food and non-food items. A non-performing loan is a debt on which the borrower is late on making payments or is in danger of missing payments. According to the international monetary fund (IMF), non- performing loan is a loan that is three months overdue. In Ghana, non -performing loans stands at 22 percent in the banking sector, as at the end of 2016. Some of the causes of non -performing loans are harsh economic conditions, high cost of operation, highinterest rates and lack of skills from the part of the bank officials [4].

\subsection{Data Source}

A secondary data on the profits of commercial banks and portfolio management were collected from the Ghana Stock Exchange and the Bank of Ghana. The variables were Government securities, investment in subsidiaries and due from other financial institutions. The total population of the banks on the Ghana Stock Exchange were eight (8). A sample size of five (5) banks on the Ghana Stock Exchange was selected for the study due to data availability. This was because the study used a period of ten (10) years starting from 2008 to 2017 where several banks were not listed during that time. The five commercial banks on the Ghana Stock Exchange that were sampled were Ecobank Ghana limited, GCB Bank Limited, CalBank Ghana Ltd, Standard Chartered Bank (GH) Limited, and Societal General Ghana Limited. The panel data was analyzed using the ordinary least square multiple regression estimation methods.

\section{Result and Discussions}

\subsection{Descriptive Statistics and Correlation}

Table 1 shows the average performance of the explanatory values that are Government securities, Investment in Subsidiaries, Due from other financial institutions, Consumer Price Index and Non- Performing Loans. The table 1 shows that investment in subsidiaries have the highest performance with a mean of 9.8 while Government Securities had a mean of 8.3. Due from other financial institution obtained a mean of 8.08. Consumer price index had a mean of 0.125 and Non - Performing loans had the least with a mean of 0.0256 . Also, the standard deviation for all predictors was relatively higher implying high variation. The variability in the predictors indicates that the financial market in Ghana is quite unstable and unpredictable.

Table 1. Descriptive statistics.

\begin{tabular}{llllll}
\hline Variables & Observation & Mean & $\begin{array}{l}\text { Standard } \\
\text { Deviation }\end{array}$ & Minimum & Maximum \\
\hline ROA & 50 & 0.03717 & 0.0155281 & 0.002 & 0.0696 \\
GS & 50 & 8.3 & 0.7287818 & 5.90082 & 9.6888 \\
INS & 50 & 9.8 & 1.370238 & 7 & 12 \\
DOFI & 50 & 8.08 & 0.7515969 & 5 & 9 \\
CPI & 50 & 0.125 & 0.04027 & 0.067 & 0.175 \\
NPL & 50 & 0.0256 & 0.048501 & -0.0367 & 0.2944 \\
\hline
\end{tabular}

Source: Authors' calculations.

Notes: ROA=Return on assets, GS=Government securities, INS=Investment in subsidiaries, $\mathrm{DOFI}=$ Due from other financial institutions, $\mathrm{CPI}=\mathrm{Consumer}$ price index, NPL=Non-performing loan.

Table 2 shows the relationship between the variables using Karl Persons coefficient correlation. The findings reveal a significant relationship between the profitability (i.e. return 
on assets) of the banks and the predictor values. A correlation coefficient of 0.3705 for Government Securities shows a positive linear relationship between the banks' profitability and Government Securities, which means that profit increases with a corresponding increase in the purchase of Government securities. Again, a correlation coefficient of 0.3433 for investment in Subsidiaries indicates a positive linear relationship between investment in Subsidiaries and the banks' profitability. This means that, investment in Subsidiaries increase with a corresponding increase in profit. Correlation coefficient for due from other financial institutions was 0.2618 impling that there was a positive relationship between due from other financial institutions and profitability, which indicates that due from other financial institutions increases with an increase in profit and vice versa. Correlation coefficient for non-performing loan was negative -0.3020 suggesting an inverse relationship between nonperforming loan and profitability which confirms the theory. In fact, this was expected as increase in the non-performing loan impacts banks revenue levels as the losses must be catered for. Correlation coefficient for consumer price index was 0.0757 indicating a positive relationship between consumer price index and profitability, which indicates that consumer price index increases with a corresponding increase in profit.

Table 2. Correlations Matrix.

\begin{tabular}{lllllll}
\hline & ROA & GS & INS & DOFI & NPL & CPI \\
\hline ROA & 1 & & & & & \\
GS & 0.3705 & 1 & & & & \\
INS & 0.3433 & 0.2957 & 1 & & & \\
DOFI & 0.2618 & 0.869 & 0.1942 & 1 & & \\
NPL & -0.302 & 0.0435 & 0.114 & -0.1394 & 1 & \\
CPI & 0.0757 & -0.0962 & 0.0599 & -0.2229 & 0.1022 & 1 \\
\hline
\end{tabular}

Source: Authors' calculations.

Notes: ROA=Return on assets, GS=Government securities, INS=Investment in subsidiaries, $\mathrm{DOFI}=$ Due from other financial institutions, $\mathrm{CPI}=\mathrm{Consumer}$ price index, NPL $=$ Non-performing loan.

\subsection{Results of Regression Analysis of Portfolio Management and Profitability of Banks}

Table 3. Model Summary and ANOVA.

\begin{tabular}{llllll}
\hline R Square & \multicolumn{2}{c}{ Adjusted R Square } & \multicolumn{3}{c}{ Sig. F Change } \\
\hline 0.3724 & 0.3011 & & \multicolumn{3}{c}{0.0008} \\
\hline \\
\hline Model & Sum of Squares & df & Mean Square & F & Sig. \\
\hline Regression & 0.004400248 & 4 & 0.00088005 & 5.22 & 0.0008 \\
Residual & 0.007414677 & 45 & 0.000168515 & & \\
Total & 0.011814925 & 49 & 0.000241121 & & \\
\hline
\end{tabular}

a. Predictors: (Constant), DOFI, INS, NPL, GS, CPI.

b. Dependent Variable: Return on Assets.

Source: Authors' calculations.

The upper part of Table 3 shows the R-squared and adjusted R-squared of the correlation coefficient. It can be seen that portfolio management significantly explains the variability of the profitability of the listed banks. The bottom part of table 3, shows the ANOVA describing whether the model is significant enough for the prediction of the profitability of the banks. The results of 0.0008 show that the predictions are statistically significant at $5 \%$.

Table 4 presents the results of the relationship between portfolio management and profitability of banks. The findings show that a unit increase in due from other financial institutions will decrease net profit by negative -0.0093038 units, holding other factors constant. A unit increase in government securities would increase net profit by 0.0151042 units if all other factors are held constant. A unit in investment in subsidiaries would increase net profit by 0.0030168 units, all things being equal. However, a unit increase in non- performing loans, all other factors held constant, would decrease net profit by negative -0.1387272 units. The results reveal that except for consumer price index, all the variables were significant in predicting the profitability of commercial banks since all the p-values were less than 0.05 . The findings suggest that holding of Government Securities, investment in subsidiaries, due from other financial institution affect the profitability of the banks.

Table 4. Coefficients of portfolio management and profitability.

\begin{tabular}{lllllll}
\hline $\begin{array}{l}\text { Independent } \\
\text { variable }\end{array}$ & Coef. & Std. Err. & $\mathbf{t}$ & $\mathbf{P}>|\mathbf{t}|$ & \multicolumn{2}{l}{ [95\% Conf. Interval] } \\
\hline Constant & -0.0429 & 0.024455 & -1.75 & 0.086 & -0.09218 & 0.0063867 \\
GS & 0.015104 & 0.0056938 & 2.65 & 0.011 & 0.003629 & 0.0265793 \\
INS & 0.003017 & 0.001435 & 2.1 & 0.041 & 0.000126 & 0.0059082 \\
DOFI & -0.0093 & 0.005558 & -1.67 & 0.101 & -0.0205 & 0.0018968 \\
CPI & 0.027695 & 0.048319 & 0.57 & 0.569 & -0.06969 & 0.1250744 \\
NPL & -0.13873 & 0.0410781 & -3.38 & 0.002 & -0.22151 & -0.0559398 \\
\hline
\end{tabular}

Source: Authors' calculation.

Notes: ROA=Return on assets, GS=Government securities, INS=Investment in subsidiaries, $\mathrm{DOFI}=$ Due from other financial institutions, $\mathrm{CPI}=\mathrm{Consumer}$ price index, NPL=Non-performing loan.

\section{Conclusion}

The objective of the paper is to investigate the effect of portfolio management on the profitability of commercial banks in Ghana. Five banks were sampled out of a population of eight banks on the Ghana Stock Exchange. A secondary data on the total value of Government securities held by banks, the total value of banks investments in subsidiaries, and the total value of funds due from other financial institutions were collected. The data were gathered from the Ghana Stock Exchange and Bank of Ghana between the periods of 2008 and 2017. The findings of the panel studies show that any increase in the purchase of Government securities increases the bank's profitability. This improved the net worth of the commercial banks. The commercial banks' managers should put in strategies and plans with regards to Government securities in their portfolios. They should develop robust strategies for managing their investment in government securities to help improve their profitability.

Further, the study revealed that investment in Subsidiaries affects the profitability of commercial banks in Ghana positively. Hence, it is recommended that commercial banks 
managers should review their investment in Subsidiaries, to realign their portfolio holdings to the desired profitability goals. This should include putting across strategies and frameworks for diversifying and utilizing the investment that translates to positive performance. In addition, the study revealed that non-performing loans affect the profitability of commercial banks in Ghana. Hence, it is recommended that commercial banks managers should upgrade their loan officers' skills and to improve upon their loan assessing procedure as well as due diligence to reduce the level of nonperforming loan. This is because an increase in the nonperforming loans will lead to a decrease in the profitability of the banks. As a recommendation for policy, this study recommends that the policymakers and the Government institutions should assist the banks by not defaulting on its repayment of government securities held by the banks. The policymakers should formulate an appropriate framework that creates conducive regulation to support portfolio management efforts by the commercial banks. This should involve a joint effort by all stakeholders to review the regulations, analyze the impact and finally adopt modern portfolio management techniques to enhance profitability.

\section{References}

[1] Adams, Donald, R. (1978). Portfolio Management and Profitability in Early-Nineteenth-Century Banking. The Business History Review. Vol. 52 (1), p. 61-79.

[2] Albertazzi, Ugo; Becker, Bo \& Boucinha, Miguel (2018). Portfolio rebalancing and the transmission of large-scale asset programmes: Evidence from the euro area. European Central Bank. Working Paper Series. No. 2125/January 2018.

[3] Anbar, Adem \& Alper, Deger (2011). Bank Specific and Macroeconomic Determinants of Commercial Banks Profitability: Empirical Evidence from Turkey. Business and Economics Research Journal. Vol. 2 (2). p. 139-152.

[4] Asiama, Rexford, K \& Amoah, Anthony (2019). Nonperforming loans and monetary policy dynamics in Ghana. African Journal of Economic and Management Studies. Vol. $10(2), 169-184$.

[5] Chakrabatrti, A., Singh, K., \& Mahmood, I. (2007). Diversification and performance: evidence from East Asian firms. Strategic Management Journal. Vol. 28 (2), p. 101-120.
[6] Chen, Andrew H; Mazumdar, Sumon, C; Surana, Rahal (2014). China's Corporate Bond Market Development. Security Design Implications of Information Asymmetry. The Chinese Economy Journal. Vol. 44 (5), p. 6-33.

[7] Durbin, Erik \& Ng, David (2005). The Sovereign ceiling and emerging market corporate bond spreads. Journal of International Money and Finance. Vol. 24 (4), p. 631-649.

[8] Hoshi, Takeo \& Kashyap, Anil K.(2010). Will the U.S Bank recapitalization succeed? Eight lessons from Japan. Journal of Financial Economics. Vol. 97 (3), p. 398-417.

[9] Kyengo, Justus M., \& Kilika, James (2017). Strategic Assets, Competitive Capabilities and Firm Performance: Review of the Literature. Journal of Business and Economic Development. Vol. 2 (3). P. 140-147.

[10] Lambert, C; Noth, F., and Schuwer, U. (2017). How do insured deposits affect bank risk? Evidence from the 2008 Emergency Economic Stabilization Act. Journal of Financial Intermediation. Vol. 29. p. 81-102.

[11] Ontita, Jane \& Kinyua, Godfrey, Muigai (2020). Role of Stakeholders Management on Firm Performance: An Empirical Analysis of Commercial Banks in Nairobi City County, Kenya. Journal of Business and Economic Development. Vol. 5 (1). P. 26-35.

[12] Oyatoye, E. O., \& Arilesere, W. O. (2012). A non-linear programimng model for insurance company investment portfolio management in Nigerian. International Journal of Data Analysis Techniques and Strategies. Vol. 4 (1), p. 83-100.

[13] Purkayastha, Saptarshi; Manolova, Tatiana, S., and Edelman, Linda, F. (2011). Diversification and Performance in Developed and Emerging Market Contexts: A Review of the Literature. International Journal of Management Reviews. Vol. 14 (1). p. 18-38.

[14] Sanya, S\& Wolfe, S. (2011). Can Banks in Emerging Economies Benefit from Revenue Diversification? Journal Finance Services Research. 40, p. 79-101. https://doi.org/10.1007/s10693-010-0098-z.

[15] Williams, Emily, Costly External Financing and Monetary Policy Transmission: Evidence from a Natural Experiment (April 20, 2020). Available at SSRN: HYPERLINK "https://ssrn.com/abstract=3080665" ไt"_blank" https://ssrn.com/abstract=3080665. 